Check for updates

The BMJ

Cite this as: $B M J 2022 ; 376: 0128$ http://dx.doi.org/10.1136/bmi.0128 Published: 18 January 2022

\section{Covid-19: Government criticised for block booking private beds to deal with omicron}

\author{
Gareth lacobucci
}

The BMA has criticised the government for striking a costly agreement to block book private hospital beds in case they are required for NHS patients in the event of a major surge in covid-19 cases.

Last week, under direction from the health secretary, Sajid Javid, NHS England agreed to pay private sector providers between $€ 75 \mathrm{~m}$ and $€ 90 \mathrm{~m}$ a month for the next three months in case they are required to provide extra bed capacity with omicron cases high. Private providers will receive the "minimum income guarantee" for being on standby even if they don't treat any NHS patients, and could receive up to $€ 525 \mathrm{~m}$ if they do.

The deal, in place from 10 January until 31 March 2022, was made despite NHS England's chief executive Amanda Pritchard warning Javid that it left the NHS "exposed financially" and represented "a material risk that the NHS pays for activity that is not performed." "On a per bed basis this is significantly more expensive than the equivalent cost of an NHS site with much less certainty on the potential staffed capacity," Pritchard warned.

Amid these warnings, the BMA's private practice committee wrote to NHS England's national medical director, ${ }^{2}$ Stephen Powis, stating that, in addition to the high cost involved, the deal would delay vital care being delivered to private patients, as happened when a similar deal ${ }^{3}$ was struck in March 2020.

"While we understand the desire to secure additional capacity, an unintended consequence of that previous agreement was that many of our members were unable to treat their patients-including those needing cancer operations and on immunosuppressives," the committee warned.

"This did not just mean a lack of value for money for the NHS and harm to private sector patients but also had a significant impact on our members," it added, noting that some doctors in private practice reported an $80 \%$ reduction in income last time such a deal was made.

The committee called for a meeting with the government to discuss what provisions it will provide for private patients whose care will be interrupted, how it has calculated the number of reserved beds needed, and what support it will provide to private practice doctors who experience a significant income reduction.

Jeremy Lawrance and Jennifer Yell, co-chairs of the committee, said, "It's shocking that the government decided to make this decision without consulting doctors working in the private sector, particularly after how unsuccessful the previous agreement was. While policy makers might think this is a good idea, doctors on the ground do not. We are of the view that this agreement will not fulfil its intention of boosting NHS capacity but rather further impact private patient care and prove to be a waste of taxpayer's money."

In a reply ${ }^{4}$ to Prichard's letter, the health secretary defended the move. "I recognise the problems that these arrangements cause for you as the accounting officer," he wrote. "However, I believe the need to protect NHS services and prevent a further reduction in NHS capacity are compelling reasons to justify their introduction."

\section{Decision. Request for direction on independent sector contracting from NHS England Chief Executive Officer to Secretary of State for Health and Social Care. 12 January 2022. www.gov.uk/government/publications/coro- navirus-covid-19-ministerial-direction-on-independent-sector-contracting/re- quest-for-direction-on-independent-sector-contracting-from-nhs-england chief-executive-officer-to-secretary-of-state-for-health-and-social-care. \\ 2 Letter to Professor Stephen H Powis National Medical Director of NHS England. www.bma.org.uk/media/4973/letter-to-professor-powis-14-jan- 2022.pdf. \\ 3 Limb M. Covid-19: Private hospitals "fell well short" in delivering care during the pandemic, says report. BMJ2021;375:n2471. doi: 10.1136/bmj.n2471 pmid: 34625407 \\ 4 Decision. Direction from Secretary of State for Health and Social Care to NHS Chief Executive Officer on independent sector contracting. 12 January 2022. 8 January 2022. www.gov.uk/government/publications/coronavirus- covid-19-ministerial-direction-on-independent-sector-contracting/direction- from-secretary-of-state-for-health-and-social-care-to-nhs-chief-executive- officer-on-independent-sector-contracting.}

This article is made freely available for personal use in accordance with BMJ's website terms and conditions for the duration of the covid-19 pandemic or unti otherwise determined by BMJ. You may download and print the article for any lawful, non-commercial purpose (including text and data mining) provided that all copyright notices and trade marks are retained. 